\title{
Risk Governance and Performance of Construction Projects in Makueni County, Kenya
}

\author{
Kelvin Rwingo Dr. Rosemary James \\ School of Business, Kenyatta University, PO box 43844-00100,Nairobi Kenya
}

\begin{abstract}
With devolved government system in Kenya, there has been a rapid increment in public construction projects. Nevertheless, performance of these projects is questionable in most counties. In Makueni County, several construction projects have had their performance compromised as evidenced by their delayed completion. The inherent risk involved in the projects is among the major reasons that lead to projects performing poorly. However, none of the existing studies have assessed how risk governance influence project performance in construction projects in Makueni County. This has resulted to lack of adequate empirical insights to guide in developing strategies for enhancing performance of construction projects in Makueni County as far as risk governance is concerned. Therefore, this study investigated the interplay between risk governance and performance of construction projects in Makueni county, Kenya. The primary objectives were to investigate the influence of resource risk management, budget control risk management and litigation risk management on performance of construction projects in Makueni County, Kenya. The research applied the descriptive research design whereby 24 projects in construction industry in Makueni County completed in year 2018/2019 were studied. The project manager, project supervisor and contractor handling each of the projects constituted the respondents. A census approach was used and thus a total of 72 respondents were targeted. To collect data, a questionnaire was administered to the respondents. Data analysis was based on descriptive and inferential statistics. The findings indicate that resource risk management in construction projects in Makueni County is good. However, inadequacy of financial resources for the project activities is a major issue. Budget control risk management and litigation risk management were also good. It was found that resource risk management, budget control risk management and litigation risk management had a positive influence on the performance of construction projects in Makueni County. The study concluded that performance of construction projects in Makueni County is significantly affected by budget control risk management while resource risk management and litigation risk management have no significant effect. The study recommends that the county government of Makueni should set aside adequate financial resources for the various construction projects to be implemented.
\end{abstract}

Keywords: Project performance, budget control risk, resource risk, litigation risk

DOI: $10.7176 / J E S D / 12-10-07$

Publication date:May $31^{\text {st }} 2021$

\section{Introduction}

Projects are paramount in the pursuit for economic growth and development among nations. Kariuki (2018) underscores that increasing high number of projects has become a conspicuous trend in both developing and developed countries worldwide, with governments largely using them in their efforts to accomplish diverse strategic development goals. In Kenya, various national development plans (such as Vision 2030) often have different projects attached to them as part of the strategies set to accomplish the envisaged goals in the development plans. Currently, development projects geared towards socio-economic development in the country are being implemented at the two levels of government - the national government and the county governments, established with the promulgation of the current constitution (Tong', Otieno \& Osoro, 2019). However, despite the high number of the projects implemented, what is fundamental to the realization of the anticipated development and growth is their performance. Mucheke and Paul (2019) underscore that performance of projects especially in the public sector is key to the achievement of national economic growth.

According to Naeem, Khanzada, Mubashir and Sohail (2018), no project is guaranteed to succeed no matter how good its planning due to unanticipated problems that arises in course of the project activities and negatively affect the project performance. This calls for the application of proper risk governance across the different project stages from its planning to completion. As Gyamfi, Zievie and Boateng (2016) highlights, construction industry is among the industries where projects are characterized by major risks related the activities involved in it. The risks probably emanate from the diversity of events and stakeholders involved construction projects including regulators, shareholders, clients, contractors among others (Omeno \& Sang, 2018). Risk governance in these projects is therefore vital as far as the performance of these projects is concerned. Gyamfi, Zievie and Boateng (2016) explains that project risk governance covers various categories with the key ones including: resource risk management, budget control risk management, and litigation risk management among others. The fundamental question is, what is the status of risk governance in the construction projects and what is the impact on the project performace? 


\subsection{Statement of the Problem}

With the devolved government system in Kenya, there has been a rapid increment in construction projects over the recent past (Mukoche, Wanjala \& Simiyu, 2018). However, performance of these projects is questionable in most counties. In Makueni County, several construction projects have had their performance compromised as evidenced by their delayed completion. Between 2014 and 2019, 9 construction projects were among 32 delayed projects in the county (Government of Makueni County, 2020). Given that poor project performance is often caused by among other factors, the inherent risks involved (Gyamfi, Zievie \& Boateng, 2016), risk governance in construction projects in the county is thus questionable. Scholars have interrogated project management and assessed aspects of project performance, but few have focused on how risk governance influences construction projects' performance in Makueni County.

For instance, Mariusz, Adnan and Isaiah (2019) investigated how risk management moderated the relationship between project planning and project performance in the construction industry in the UK and Pakistan. However, although they assessed risk management in their study, they assessed it not as an independent variable that affects project performance, but as a moderating variable. Gitahi and Tumuti (2019) analyzed how contracting risk management affect projects' performance in construction industry in the county of Kilifi. Although they assessed influence of management of diverse risks on project performance, the results may not apply in construction projects in Makueni County since project risks and their management vary from one context to another. Others like Maendo,James and Kamau (2018), Mwadime and Rosemary (2019) and Muute and James (2019) investigated how construction projects' perfomance is influeneced by M \& E, relationship management, and project planning practices respectively. It is therefore apparent that existing literature lacks adequate empirical insight to explain the relationship between risk governance and construction projects' performance in Makueni County. To address these inadequacies, this study investigated risk governance and how it influences perfomance of construction projects' in Makueni County. The objectives of the study were:

(i) To investigate the influence of resource risk management on performance of construction projects in Makueni County, Kenya

(ii) To assess the influence of budget control risk management on performance of construction projects in Makueni County, Kenya

(iii) To investigate the influence of litigation risk management on performance of construction projects in Makueni County, Kenya.

\subsection{Literature Review}

\subsection{Theoretical Review}

Two main theories were applied in carrying out the study: resource dependency theory and the theory of constraints. Pfeffer and Salancik (1978) are the proponents of the resource dependency theory. The theory asserts that in any organization, resources are fundamental to the firm's survival in the long run. It further states that organizations can only get the resources within their respective environments, and this is threatened by the existence of other organizations competing for the very resources within same environment. The resource dependency theory affirms uncertainty of resources as one of the major problems confronting organizations. According to the theory, this revolves around three aspects: resource concentration, availability of the resources, and interconnectedness of the resources (Zehir, Findikli \& Celtekligil, 2018). In this research therefore, the theory informed the assessment of the resource risk management and the budget control risk in the lights of these aspects.

Goldratt and Cox (1984) proposed the theory of constraints. It asserts that there external and internal constraints affecting the achievement of goals and objectives in any given project. The theory therefore emphasizes that for the performance of a project to be optimized within the distinct constraints identified and their effect (Omeno \& Sang, 2018). To this end, the theory proposes five steps to achieve desired performance within the constraints. These are: identifying the constraints, developing measures to exploit the constraints identified, prioritizing the measures developed to exploit the constraints, implementing the measures to obtain maximum productivity from the constraint, and monitoring and evaluating the management of the constraint for continuous improvements (Gitahi \& Tumuti, 2019). This theory was largely applied in this study to assess the management of litigation risks, resource risks and budget control risks in construction projects both from external and internal environment. The theory helped to interrogate the risk governance process in the projects and assess the impact on the project performance.

\subsection{Empirical review}

\subsubsection{Resource Risk Management and Project Performance}

In their study, Jayasudha, Vidivelli and Surjith (2014) investigated the assessment and management of resource risks in construction projects in India. The findings revealed that resource risk assessment and management had a significant effect on project performance. However, the researchers only used descriptive statistics and did not use regression analysis to assess how resource risk management influenced project performance. In contrast, 
descriptive statistics as well as regression analysis were applied in this research for a more comprehensive analysis. Irfandhi (2016) in their investigation on management of risks in IT projects identified resource risk management as major factor that negatively affected project performance. Since projects differ in their uniqueness and consequently the risks involved based on their industry and geographical context, the results may not apply to construction projects in Makueni County. This is particularly because the findings are based on IT projects context which differs from construction projects context.

\subsubsection{Budget Control Risk Management and Project Performance}

In a study assessing constraints in projects within Nairobi, Rugenyi (2015) found that budget control risk was a major constraint and its management determined project performance. The study was however too general in scope since it was not confined to any specific category of projects. As such, the findings cannot be reliably generalized to a specific category of projects like construction projects.

Rehacek and Bazsova (2018) investigated budget control risk management and indicated that budget control risk management influenced performance of construction projects. However, the study adopted a desktop survey approach that was exclusively based on secondary data review. Therefore, the findings do not reflect the situation in construction projects in any specific context. Moreover, the study did not investigate how the risks were related to the projects performance.

Hatefi (2018) investigated risk factors and their management in an oil and gas project in Iran. Aspects of budget control risks whose management was found to strongly affect the project performance included: lack of accurate information, overemphasis on design and technical specifications, invalid project assumptions and bad estimations. Although the study was quite thorough and detailed in assessing the risks and their management, it used a case study design while the current study applied the descriptive survey design.

\subsubsection{Litigation Risk Management and Project Performance}

Kishan, Bhatt and Bhavsar (2014) identified legal risk as a major risk affecting project performance in their research. This study was however based on literature review methodology where it exclusively reviewed existing literature to derive its conclusions. Moreover, the study did not investigate on how the risks are managed and how this impacts the performance of the projects.

In their research on management of risks in construction industry, Renault and Agumba (2016) found that litigation risk management was a major factor that influenced projects performance. However, the study applied the literature review methodology alone with no specific focus on projects in any context. Based on the methodology used therefore, the findings cannot sufficiently and accurately describe the present situation in the construction projects.

Elijah (2017) assessed the influence of management of risks on construction projects' performance in Nakuru, Nairobi and Machakos counties in Kenya. Findings revealed that management of litigation risks did not significantly affect project's performance. However, Elijah (2017) did not consider the indicators that were used in this research including: compliance to construction regulations, compliance to procurement regulations, compliance to environmental regulations, and frequency of legal compliance related disputes.

\section{Research Methodology}

Undertaking the study was anchored on the descriptive research design. The construction projects completed in the year 2018/2019 in Makueni County constituted the population. Records from the Government of Makueni County (2020) indicate that a total of 24 construction projects were completed in the year 2018/2019. Since 24 projects are too few to sample, the census approach was used. This is in line with Kothari (2004) who suggested that when the target population is too small, sampling is unnecessary and the census approach is more suitable to use. The project manager, project supervisor and contractor handling each of the 24 construction projects constituted the respondents in this study. Therefore, the 24 projects that were covered had a total of 72 respondents (24 X 3) that were targeted.

A questionnaire was administered to the respondents for data collection through drop and pick later method.. However, those who insisted to be engaged via email had the questionnaire sent to their respective email for them to complete and send it back within the agreed date. Once the data was collected, data coding was done where the responses were coded in readiness for data entry. Data entry was done in SPSS v.25. Once the data was entered, descriptive and inferential statistics were computed. The former entailed frequency, percentage, mean and standard deviation to assess and explain the distribution of the responses for various items in the questionnaire. Then, inferential statistics were used to analyze the data in line with the objectives of the study. In this case, correlation analysis and regression analysis were computed. For regression analysis, multiple linear regression analysis was computed. In this regard, the regression model took the form:

$$
\mathrm{Y}=\beta_{0}+\beta_{1} \mathrm{X}_{1}+\beta_{2} \mathrm{X}_{2}+\beta_{3} \mathrm{X}_{3}+\mathrm{e}
$$

$\mathrm{Y}$ is the dependent variable - project performance

$\mathrm{X}_{1}, \mathrm{X}_{2}$, and $\mathrm{X}_{3}$ are the independent variables - resource risk management, budget control risk management, and litigation risk management respectively 
$\beta_{1}, \beta_{2}$, and $\beta_{3}$ are the regression coefficients - coefficients for resource risk management, budget control risk management, and litigation risk management respectively

$\beta_{0}$ is the regression constant

$\mathrm{e}$ is the error term

\section{Research Findings and Discussion}

\subsection{Descriptive Statistics}

The descriptive statistics for the various aspects of each of the study variables were computed and assessed based on respondents' agreement or disagreement with the various statements provided for the respective variable. The scale was used was $1-5$ where 1 was strongly disagree and 5 was strongly agree.

Table 1: Resource risk management in the construction projects

\begin{tabular}{lccc}
\hline Statement & N & Mean & Std. dev \\
\hline $\begin{array}{l}\text { The financial resources were readily available and adequate for the for the } \\
\text { different project activities }\end{array}$ & 38 & 2.45 & 0.98 \\
The construction materials were availed in time for the various project & 38 & 3.87 & 0.58 \\
activities & & & 0.55 \\
The construction materials were adequate for the various project activities & 38 & 4.39 & 0.55 \\
$\begin{array}{l}\text { All the capital equipment needed for the project were available and suitable } \\
\text { for use throughout the project period }\end{array}$ & 38 & 4.55 & 38 \\
Human resources was readily available and adequate for the project & 4.61 & 0.64 \\
\hline Overall & & 3.97 & 0.66 \\
\hline
\end{tabular}

From table 1, the overall resource risk management in construction projects by the county government of Makueni was good (mean $=3.97$, std. dev $=0.66$ ). The findings indicate that in most of the projects, human resources, capital equipment and construction materials were available and adequate as indicated by their high means of 4.61, 4.55 and 4.39 respectively. However, the financial resources were not readily available and adequate for the project activities (mean $=2.45$, std. $\mathrm{dev}=0.98$ ). Similar situation was reported by Jayasudha, Vidivelli and Surjith (2014) in the case of construction projects in India where they indicated that the projects had major financial resources risk.

Table 2: Budget control risk management in the construction projects

\begin{tabular}{|c|c|c|c|}
\hline Statement & $\mathbf{N}$ & $\begin{array}{c}\text { Mea } \\
\text { n }\end{array}$ & $\begin{array}{l}\text { Std. } \\
\text { dev }\end{array}$ \\
\hline There was high precision in cost estimation in the project budget & 38 & 3.76 & 0.68 \\
\hline $\begin{array}{l}\text { There were minimal budget overruns in the course of undertaking the various } \\
\text { project activities }\end{array}$ & 38 & 3.87 & 0.58 \\
\hline There were minimal deviations from the project activities schedule & 38 & 3.89 & 0.95 \\
\hline There were no major changes in layout design during the undertaking of the project & 38 & 4.89 & 0.31 \\
\hline Overall & & 4.11 & 0.63 \\
\hline
\end{tabular}

As evident in table 2, budget control risk management was also quite good at an average mean score of 4.11 with a std. dev of 0.63 . In most of the projects, respondents strongly asserted that there were no major changes in layout design during the undertaking of the project (mean $=4.89$, std. dev $=0.31$ ). The findings differs from the findings by Rehacek and Bazsova (2018) who found that budget control risks in terms of cost overruns and scheduling risks were common in many projects.

Table 3: Litigation risk management in the construction projects

\begin{tabular}{|c|c|c|c|}
\hline Statement & $\mathbf{N}$ & Mean & $\begin{array}{l}\text { Std. } \\
\text { dev }\end{array}$ \\
\hline The project complied with all the requisite construction regulations & 38 & 4.11 & 0.61 \\
\hline $\begin{array}{l}\text { Procurement of all the materials used was done with strict compliance to the set } \\
\text { procurement regulations }\end{array}$ & 38 & 4.42 & 0.50 \\
\hline $\begin{array}{l}\text { All the environmental regulations were complied with during the undertaking of } \\
\text { the project }\end{array}$ & 38 & 4.05 & 0.80 \\
\hline $\begin{array}{l}\text { There were minimal disputes related to legal requirements compliance during the } \\
\text { undertaking of the project }\end{array}$ & 38 & 4.63 & 0.54 \\
\hline Overall & & 4.30 & 0.61 \\
\hline
\end{tabular}

Litigation risk management was the highest (compared to resource risk management and budget control risk management) at an average mean score of 4.30 with a std. dev of 0.61 as indicated in table 3 . In majority of the projects, there were minimal disputes related to legal requirements compliance during the undertaking of the project $($ mean $=4.63$, std. dev $=0.54)$. The findings disagrees with Kishan, Bhatt and Bhavsar $(2014)$ whose study found out major legal risks in the projects investigated which were found to cause schedule delays and cost 
overruns.

Table 4: Project performance of the construction projects

\begin{tabular}{lccc}
\hline Statement & N & $\begin{array}{c}\text { Mea } \\
\mathbf{n}\end{array}$ & $\begin{array}{c}\text { Std. } \\
\text { dev }\end{array}$ \\
\hline The cost of most of the project activities in the project was within the cost estimates & 38 & 4.08 & 0.27 \\
in the budget & 38 & 4.05 & 0.52 \\
There were minimal cost overruns in completion of the project. & 38 & 2.00 & 0.74 \\
The whole project was completed within the set timeline. & 38 & 2.47 & 0.69 \\
Most of the project activities were completed within their scheduled time & 38 & 3.84 & 0.72 \\
After its completion, the project enhanced the citizens' access to better services. & 3.29 & 0.59 \\
\hline Overall & & 3.29 \\
\hline
\end{tabular}

Table indicates that performance of the construction projects was rated at 3.29 out of 5 . In majority of them, the cost of most of the project activities was within the cost estimates in the budget (mean $=4.08$, std. dev $=0.27$ ). However, the projects were not completed within the set timeline $($ mean $=2.00$, std. $\mathrm{dev}=0.52)$ and most of the project activities were not completed within their scheduled time (mean $=2.47$, std. dev $=0.69)$. Even so, after their completion, most of the project enhanced the citizens' access to better services (mean $=3.84$, std. $d e v=0.72)$.

\subsection{Inferential Statistics}

Inferential statistics were computed to analyze how the study variables were related; particularly the relationship between project performance [PP] and: resource risk management (RRM), budget control risk management (BCRM) and litigation risk management (LRM). In this regard, correlation and regression analysis were done.

Table 5: Correlation Analysis

\begin{tabular}{llllll}
\hline & & PP & RRM & BCRM & LRM \\
\hline PP & Correlation Coefficient & 1.000 & $.370^{*}$ & $.553^{* *}$ & .097 \\
\cline { 2 - 5 } & Sig. (2-tailed) &. & .022 & .000 & .564 \\
\hline \multirow{2}{*}{ RRM } & $\mathrm{N}$ & 38 & 38 & 38 & 38 \\
& Correlation Coefficient & $.370^{*}$ & 1.000 & .057 & -.098 \\
& Sig. (2-tailed) & .022 &. & .736 & .559 \\
\hline \multirow{2}{*}{ BCRM } & $\mathrm{N}$ & 38 & 38 & 38 & 38 \\
& Correlation Coefficient & $.553^{* *}$ & .057 & 1.000 & .246 \\
\hline \multirow{2}{*}{ LRM } & Sig. (2-tailed) & .000 & .736 &. & .137 \\
& $\mathrm{~N}$ & 38 & 38 & 38 & 38 \\
& Correlation Coefficient & .097 & -.098 & .246 & 1.000 \\
& Sig. (2-tailed) & .564 & .559 & .137 &. \\
\hline & $\mathrm{N}$ & 38 & 38 & 38 & 38 \\
\hline
\end{tabular}

*. Correlation is significant at the 0.05 level (2-tailed).

**. Correlation is significant at the 0.01 level (2-tailed).

The correlation between resource risk management and project performance $(r=0.370)$ is significant because the p-value ( $\mathrm{Sig} .=0.022)$ is less than 0.05 . This implies that resource risk management significantly affects project performance. This concurs with Jayasudha, Vidivelli and Surjith (2014) who found that resource risk management had a significant effect on project performance.

Similarly, the correlation between budget control risk management and project performance $(r=0.553)$ is significant because the p-value $(\mathrm{Sig} .=0.000)$ is less than 0.05 . This implies that budget control risk management significantly affects project performance. This agrees with the findings by Hatefi (2018) that indicated that budget control risks management significantly affects project performance.

However, the correlation between litigation risk management $(r=0.097)$ and project performance is not significant because the p-value (Sig. $=0.564$ ) is greater than 0.05 . This implies that litigation risk management has insignificant effect on project performance. This is congruent to the findings by Elijah (2017) that indicated that litigation risks did not have a significant effect on project's performance.

Table 6: Model summary

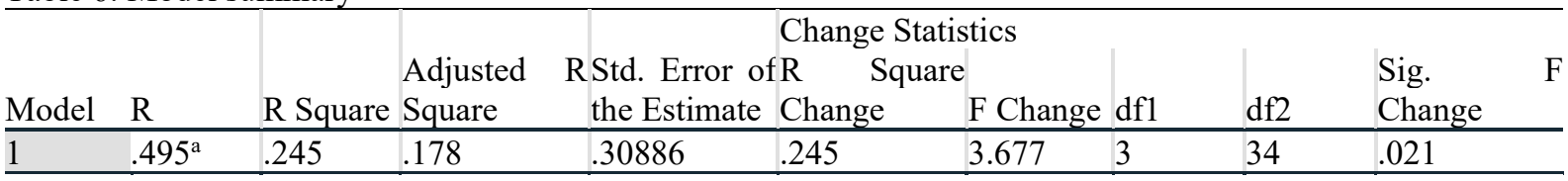

\section{a. Predictors: (Constant), RRM, BCRM, LRM}

Table 6 indicates that the R Square value was 0.245 . This R Square value means that $24.5 \%$ of the change in the performance of the construction projects is determined by RRM, BCRM and LRM collectively. The relatively 
low R Square means that performance of construction projects is affected by many other factors apart from RRM, BCRM and LRM.

Table 7: Analysis of variance (ANOVA)

\begin{tabular}{ll|c|c|c|c|c}
\hline Model & & Sum of Squares & df & Mean Square & F & Sig. \\
\hline 1 & Regression & 1.052 & 3 & .351 & 3.677 & $.021^{\mathrm{b}}$ \\
\cline { 2 - 7 } & Residual & 3.243 & 34 & .095 & & \\
\cline { 2 - 7 } & Total & 4.296 & 37 & & & \\
\hline
\end{tabular}

a. Dependent Variable: PP

b. Predictors: (Constant), RRM, BCRM, LRM

As indicated in Table 7, the F-value was 3.677 with a p-value of 0.021 . Since the p-value is less than 0.05 , then the F-value is significant. That means the regression model estimated based on the data used is significant (at the 0.05 significance level) in describing the influence of resource risk management, budget control risk management and litigation risk management on project performance.

Table 7: Regression coefficients

\begin{tabular}{|c|c|c|c|c|c|c|}
\hline \multirow{2}{*}{\multicolumn{2}{|c|}{ Model }} & \multicolumn{2}{|c|}{ Unstandardized Coefficients } & \multirow{2}{*}{$\begin{array}{c}\text { Standardized } \\
\text { Coefficients } \\
\text { Beta } \\
\end{array}$} & \multirow[b]{2}{*}{$\mathrm{t}$} & \multirow[b]{2}{*}{ Sig. } \\
\hline & & $\mathrm{B}$ & Std. Error & & & \\
\hline \multirow[t]{4}{*}{1} & (Constant) & .407 & 1.023 & & .398 & .693 \\
\hline & RRM & .208 & .126 & .248 & 1.656 & .107 \\
\hline & BCRM & .349 & .140 & .379 & 2.501 & .017 \\
\hline & LRM & .145 & .185 & .119 & .786 & .437 \\
\hline
\end{tabular}

a. Dependent Variable: PP

Using the regression coefficients as derived in table 4.7, the regression model for the influence of risk governance on project performance was:

$\mathrm{Y}=0.407+0.208 \mathrm{X}_{1}+0.349 \mathrm{X}_{2}+0.145 \mathrm{X}_{3}$

The regression coefficient for resource risk management was 0.208 , an indication that resource risk management positively affects project performance. This implies that enhancement of resource risk management improves performance of the construction projects. However, the coefficient was insignificant with a $p$-value $=$ 0.107 which is greater than 0.05. This finding differs from Irfandhi (2016) who found that resource risk management in IT projects negatively affected project performance. The difference could be attributed to the manner in which the resource risk was managed in the two different categories of projects.

The regression coefficient for budget control risk management was 0.349 , an indication that budget control risk management positively influences project performance. This implies that enhancement of budget control risk management improves performance of the construction projects. The coefficient was significant with a $p$-value $=$ 0.017 which is less than 0.05 . This finding agrees with Rugenyi (2015) who found that budget control risk management was a significant factor that positively affected project performance.

The regression coefficient for litigation risk management was 0.145 an indication that litigation risk management positively influences project performance. This implies that enhancement of litigation risk management improves performance of the construction projects. However, the coefficient was insignificant with a $\mathrm{p}$-value $=0.437$ which is greater than 0.05. This finding differs from Renault and Agumba (2016) who found that litigation risk management was a significant factor that influenced projects performance.

\section{Conclusion}

First, the study concluded that among the three aspects of risk governance investigated (resource risk management, budget control risk management and litigation risk management) in construction projects by Makueni County government, budget control risk management exerts the strongest influence on project performance. It is concluded that resource risk management exerts insignificant positive effect on projects' performance. The study concludes that budget control risk management has a significant positive effect on the projects' performance. The study also concludes that although litigation risk management is very good in the construction projects by Makueni County government, it has an insignificant effect on the projects' performance.

\section{Recommendations}

The study suggests that the county government of Makueni should make sure that they set aside adequate financial resources for the various construction projects to be implemented. The huge proportion of resources during budgeting should be channeled towards the main project activities. Lastly, the project management teams in charge of the construction projects should continue complying with all the legal requirements is not overemphasized at expense of other risk governance aspects like resource risk management. 


\section{References}

Elijah, O. A. (2017). Risk management strategies and performance of construction firms in selected counties in Kenya. Unpublished Doctorate Thesis. Kenyatta University, Nairobi.

Gitahi, S. M. \& Tumuti, J. (2019). Management of contracting risks on performance of construction projects in Kilifi County, Kenya. International Academic Journal of Information Sciences and Project Management, 3(3), 105-130.

Goldratt, E. M. \& Cox, J. (1984). The goal, croton-on-hudson. NY: North River Press Inc.

Government of Makueni County (2020). Makueni County projects management system. Retrieved from: https://makueni.go.ke/projects/public/stalled.php

Gyamfi, T. A., Zievie, P. \& Boateng, V. (2016). Risk management of procurement challenges: The implication to construction firms in Ghana. American Journal of Engineering Research, 5(8), 164-172.

Hatefi, M. A. (2018). Assessment of risk factors of a completed oil and gas project, with the use of a hybrid EVMSAW method. Journal of Energy Management and Technology, 2(1), 42-53.

Irfandhi, K. (2016). Risk management in information technology project: An empirical study. ComTech, 7(3), 191199.

Jayasudha, K., Vidivelli, B. \& Surjith, E. R. (2014). Risk assessment and management in construction projects. International Journal of Scientific \& Engineering Research, 5(8), 387-396.

Kariuki, J. T. (2018). The effect of project manager's leadership style on performance of water projects in Kenya. European Scientific Journal, 14(17), 33-45.

Kishan, P., Bhatt, R. \& Bhavsar, J. J. (2014). A study of risk factors affecting building construction projects. International Journal of Engineering Research \& Technology, 3(12), 831-835.

Kothari, C. R. (2004). Research Methodology: Methods and Techniques (2nd ed.). New Delhi: New Age International (P) Ltd Publishers.

Mariusz, U., Adnan, H. \& Isaiah, O. (2019). The moderating role of risk management in project planning and project success: Evidence from construction businesses of Pakistan and the UK. Engineering Management in Production and Services, 11(1), 23-35.

Mucheke, J. \& Paul, S. N. (2019). Factors influencing performance of road construction projects in Nairobi City County, Kenya. International Journal of Entrepreneurship and Project Management, 4(2), 85-103.

Mukoche, W. C., Wanjala, K. B. \& Simiyu, J. W. (2018). Contribution of quality assurance practices by contractors on quality of public building projects in Kenya by devolved units: A case of Busia County in Western region, Kenya. International Journal of Advance Research, Ideas and Innovations in Technology, $4(5), 356-360$.

Naeem, S., Khanzada, B., Mubashir, T. \& Sohail, H. (2018). Impact of project planning on project success with mediating role of risk management and moderating role of organizational culture. International Journal of Business and Social Science, 9(1), 88-98.

Omeno, B. K. \& Sang, P. (2018). Project management and performance of public sector construction projects: A case of constituency development funds projects in Migori East, Kenya. International Journal of Current Aspects in Project Management, 1(1), 13-26.

Pavan, G. K. \& Kulkarni, N. (2014). Research methodology: Review article. International Journal of Innovative Research and Development, 3(7), 168-173.

Pfeffer, J. \& Salancik, G. R. (1978). The external control of organizations: A resource dependence perspective. NY: Harper and Row

Rehacek, P. \& Bazsova, B. (2018). Risk management methods in projects. Journal of Eastern Europe Research in Business and Economics, 2018, 1-11.

Renault, B. Y. \& Agumba, J. N. (2016). Risk management in the construction industry: A new literature review. MATEC Web of Conferences, 66(00008), 1-6.

Rugenyi, F. (2015). Assessment of the triple constraints in projects in Nairobi: The project managers' perspective. International Journal of Academic Research in Business and Social Science, 5(11), 1-16.

Singh, A. P. (2014). A review on research design and its important parameters. International Journal of Advance Research in Science and Engineering, 3(7), 319-324.

Tong', J. N., Otieno, M. \& Osoro, H. K. (2019). Effects of monitoring and evaluation process on the performance of county government projects in Kisii County, Kenya. International Journals of Academics \& Research, $1(2), 81-92$

Zehir, C., Findikli, M. A. \& Celtekligil, K. (2018). Resource dependence theory, firm performance and producerssuppliers relationships. Proceedings of the Joint Conference: 14th ISMC and 8th ICLTIBM-2018. Retrieved from: https://dx.doi.org/10.15405/epsbs.2019.01.02.14 